\title{
Subcutaneous Abscess Secondary to Xanthogranulomatous Cholecystitis
}

\author{
Abcesso Subcutâneo Secundário a Colecistite Xantogranulomatosa
}

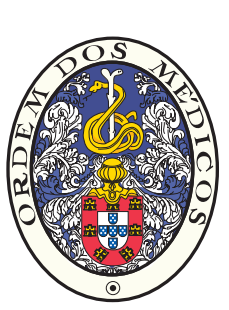

\author{
Hugo CORREIA ${ }^{1}$, Alexandre MOTA ${ }^{1}$, Daniel CARDOSO ${ }^{1}$, Gabriel GEREDIAGA $^{1}$ \\ Acta Med Port 2014 Jul-Aug;27(4):511-514
}

\section{ABSTRACT}

One of the known complications of gallstones consists in gallbladder perforation with cholecystocutaneous abscesses or external fistulas formation. Nowadays these types of complications are uncommon, having been more frequent. The authors report the case of an 86 year-old woman, bedridden and dependent, referred to our institution by presenting a tumefaction with inflammatory signs in the right upper quadrant. The radiological investigation revealed it to be a subcutaneous abscess associated with a perforated gallbladder, whose histological analysis revealed xanthogranulomatous cholecystitis.

Keywords: Abscess; Cholecystitis; Granuloma; Xanthomatosis; Subcutaneous Tissue.

\section{RESUMO}

Uma das complicações conhecidas da litíase vesicular consiste na perfuração da vesícula com consequente formação de abcessos colecisto-cutâneos ou trajectos fistulosos externos. Actualmente este tipo de complicação é pouco frequente na prática diária, tendo sido mais frequente. Os autores relatam o caso de uma senhora de 86 anos, acamada e dependente, referenciada à nossa instituição por apresentar uma tumefacção no quadrante superior direito, com sinais inflamatórios associados. A investigação imagiológica da referida tumefacção revelou tratar-se de um abcesso subcutâneo associado a perfuração da vesicula biliar, cuja análise histológica revelou colecistite xantogranulomatosa.

Palavras-chave: Abcesso; Colecistite; Granuloma; Xantomatose; Tecido Subcutâneo.

\section{INTRODUCTION}

Complications of stone-related gallbladder disease can involve the presence of fistulous tracts, which can be internal and responsible of gallbladder ileus and Mirizzi syndrome. But biliary fistulous tracts can also be external and complicate gallstone disease; however, nowadays external biliary fistulous tracts are rare.

\section{CLINICAL CASE}

An elderly 86 year-old woman, bedridden and dependent in a nursing home, was brought to the emergency department of our institution due to the presence of a tumefaction in the right upper quadrant with inflammatory signs. There were no other complaints, and the remaining clinical data was irrelevant to this case. At physical examination she was apyretic, agitated and disoriented, with a tumefaction in the right upper quadrant, with overlying erythema, mild fluctuation and tenderness at palpation. Laboratorial analysis revealed elevated white cell blood count and C-reactive protein.

Ultrasound examination was performed in order to rule out an intra-abdominal infection with spontaneous drainage, and the results confirmed a subcutaneous collection (Fig. 1) with suggestion of a communicating tract with the gallbladder fundus. The gallbladder was not satisfactorily visualized so an abdominal computed tomography (CT) was performed.

Abdominal CT confirmed the presence of gallbladder fundus inflammatory signs (figure 2) with a communication tract (Fig.s 3, 4) dissecting the muscular plane (Fig. 4) between the gallbladder fundus and the clinically palpable collection, with peripheral fat stranding (Fig. 5).

The collection was first drained externally and the patient underwent open cholecystectomy after; during surgery lysis of adhesions of the gallbladder to the duodenum and colon were performed, and the communication tract between the gallbladder and the collection was identified with removal of gallstones at this level. Macroscopic analysis revealed a scleroatrofic gallbladder with thick brownish wall containing biliary sludge; microscopic analysis was compatible with xanthogranulomatous cholecystitis.

\section{DISCUSSION}

External biliary fistulous tracts can complicate gallstone disease, but can occur secondary to biliary injury during a surgical procedure, cholangiocarcinoma and other causes. Nowadays they are rare, however they were common in the past, being the first report from $1670 .^{2}$ Generally, the fistulas or abscesses appear in the right upper quadrant, although other locations such as the epigastrium, umbilical area, right groin and even the gluteal region have been described. ${ }^{3}$

The triggering factor of this condition is associated with increased pressure in the gallbladder secondary to cystic duct obstruction, either caused by a calculus or neoplasia. The increase in intraluminal pressure leads to impairment of the blood flow supply and lymph drainage off the gallbladder, thus causing mural necrosis and perforation. ${ }^{3}$

In approximately $5 \%$ to $10 \%$ of patients, cholecystitis

1. Serviço de Imagiologia. Centro Hospitalar Tondela-Viseu. Viseu. Portugal.

Recebido: 26 de Agosto de 2013 - Aceite: 07 de Janeiro de 2014 | Copyright @ Ordem dos Médicos 2014 


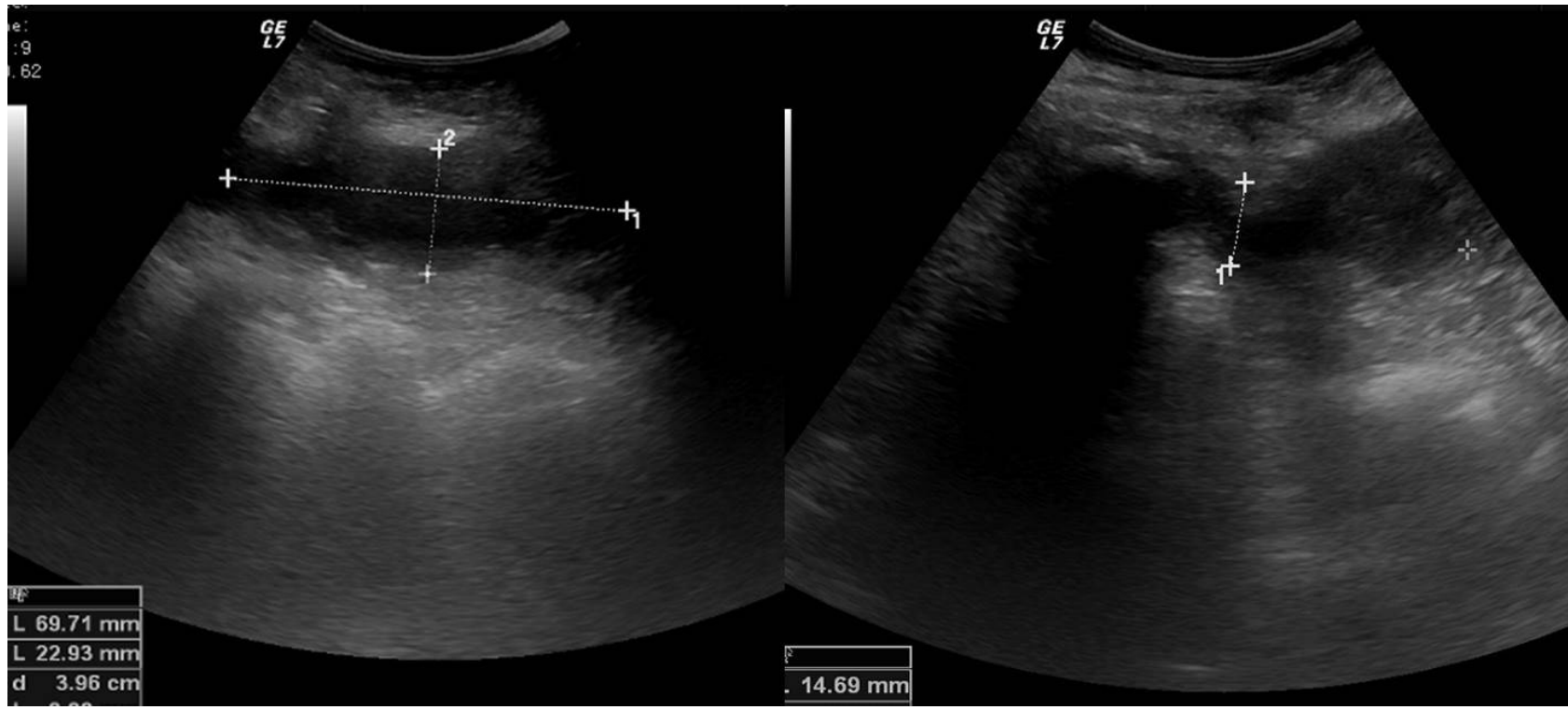

Figure 1 - Ultrasound images depicting the irregular subcutaneous collection and suggesting a fistulous tract

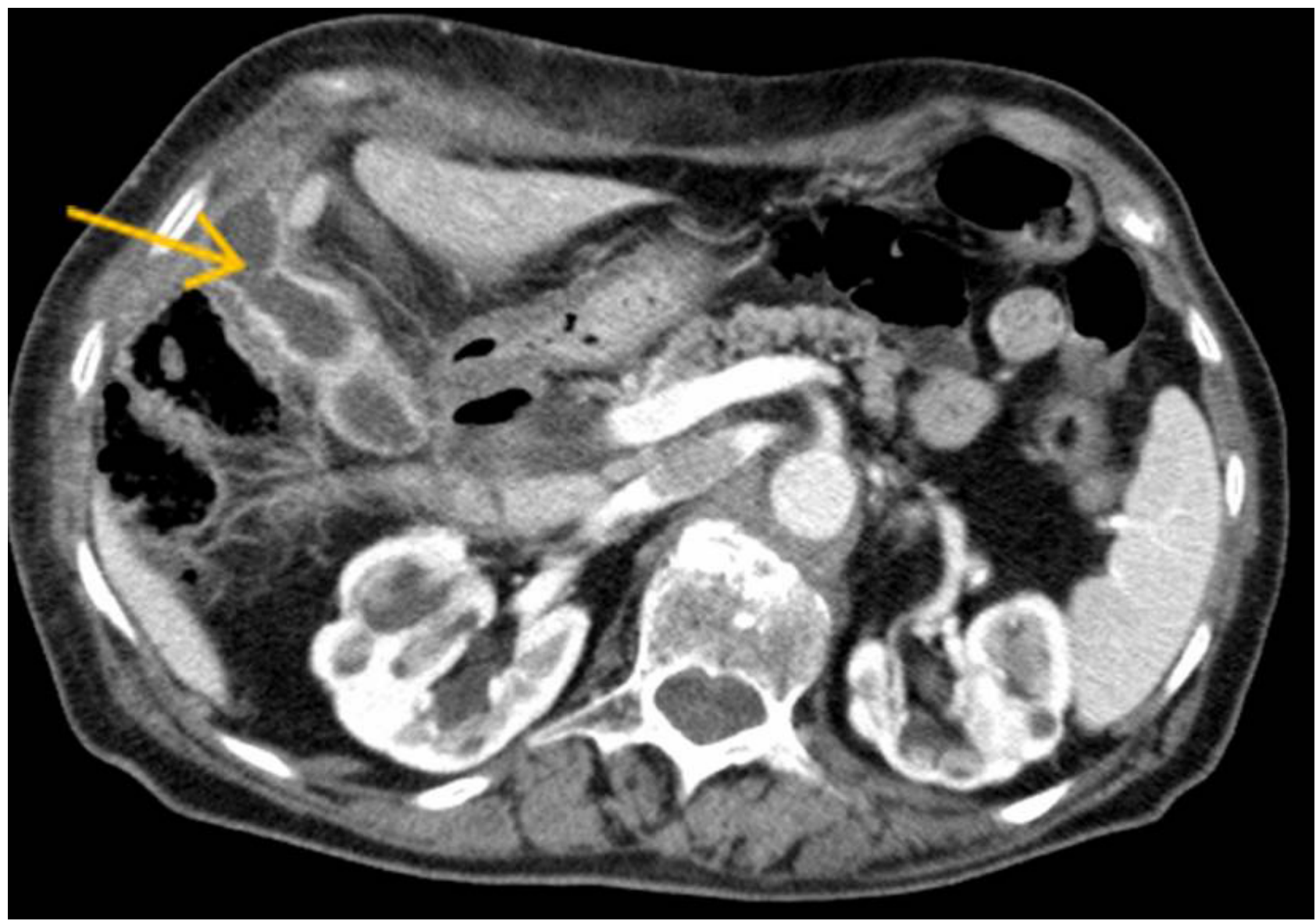

Figure 2 - Transversal enhanced CT image demonstrating hyper-enhancing fundus wall with focal discontinuity (arrow)

occurs without gallstones. ${ }^{4}$ It is most seen in severe ill patients, often following trauma, surgery or major burns. The exact etiology is not fully understood, but ischemia, hypotension or sepsis, are likely contributing factors. ${ }^{5}$ Gangrene of the gallbladder occurs in 40 to $60 \%$ of these patients, who also have an increased risk of perforation, being the mortality rate higher than in lithiasic acute cholecystitis. ${ }^{5}$ External biliary fistulous tracts can also complicate acalculous cholecystitis, being the first report dated from 1991 by Birch. ${ }^{6}$

According to Niemeier ${ }^{7}$ perforation can occur as acute free perforation into the peritoneal cavity leading to 


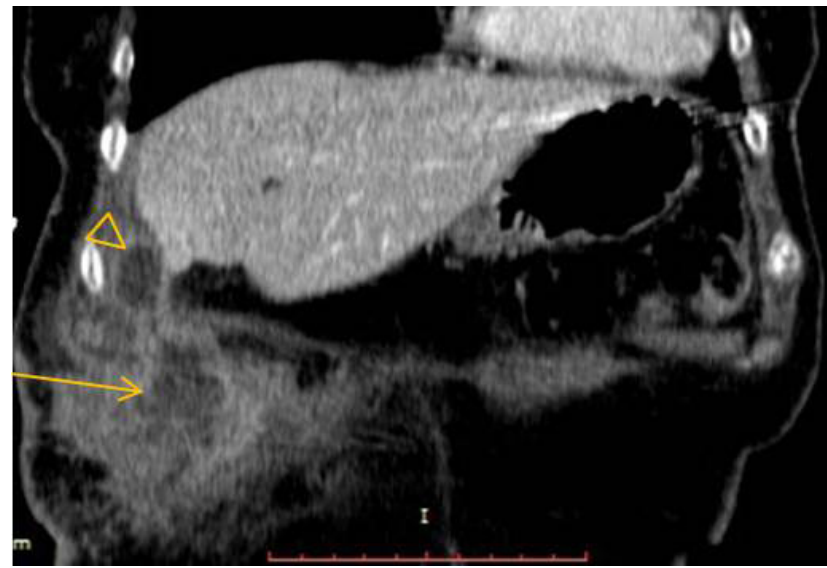

Figure 3 - Coronal reformatted enhanced CT image depicting the communication tract between the gallbladder fundus (arrowhead) and collection (arrow)

peritonitis, can be subacute resulting in an abscess around the gallbladder, or can be chronic with subsequent formation of an internal or external biliary fistula. The latter frequently arise from the fundus of the gallbladder as in this case. Nayman in $1963^{8}$ coined the state preceding spontaneous rupture has 'empyema necessitatis' of the gallbladder.

Beside perforation and abscess formation other complications of gallstones include gallstone ileus, characterized by mechanical obstruction of the small bowel because of an impacted gallstone, usually due to fistula formation between the gallbladder and adjacent viscera. The most common sites of impaction are the ileum (54-

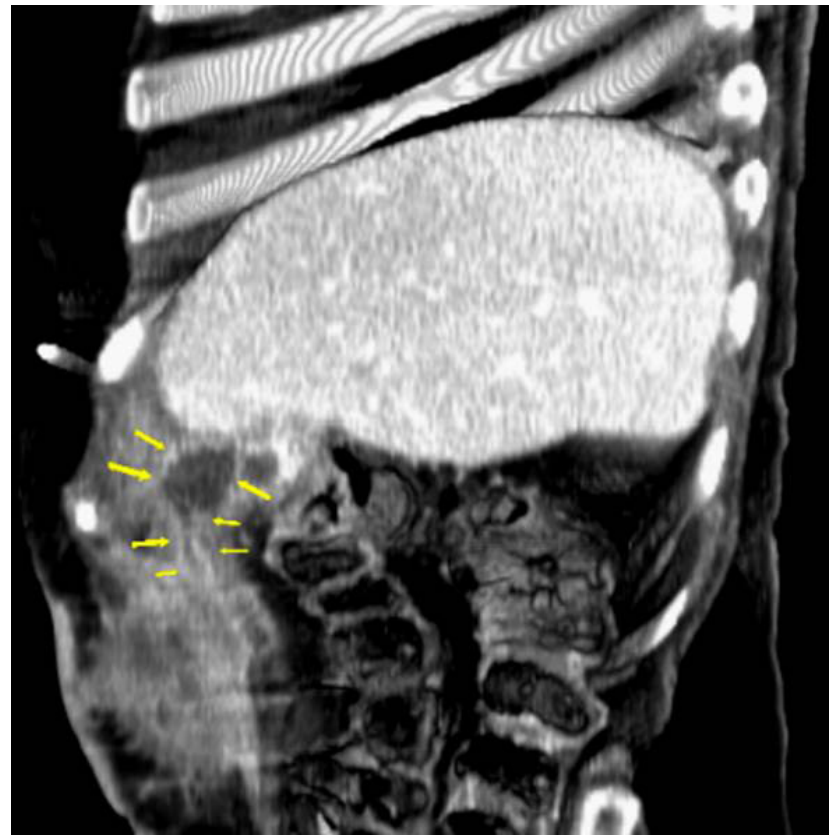

Figure 4 - Sagittal thick reformatted enhanced CT image demonstrating the communication tract with the gallbladder fundus

$65 \%$ ), jejunum (27\%), and duodenum (1-3\%). ${ }^{4}$ Regarding this latter location, when the gallstone lodges at the duodenum or pylorus causing gastric outlet obstruction, this is referred as 'Bouveret's syndrome'.

Xanthogranulomatous cholecystitis is a rare chronic inflammatory condition of the gallbladder characterized

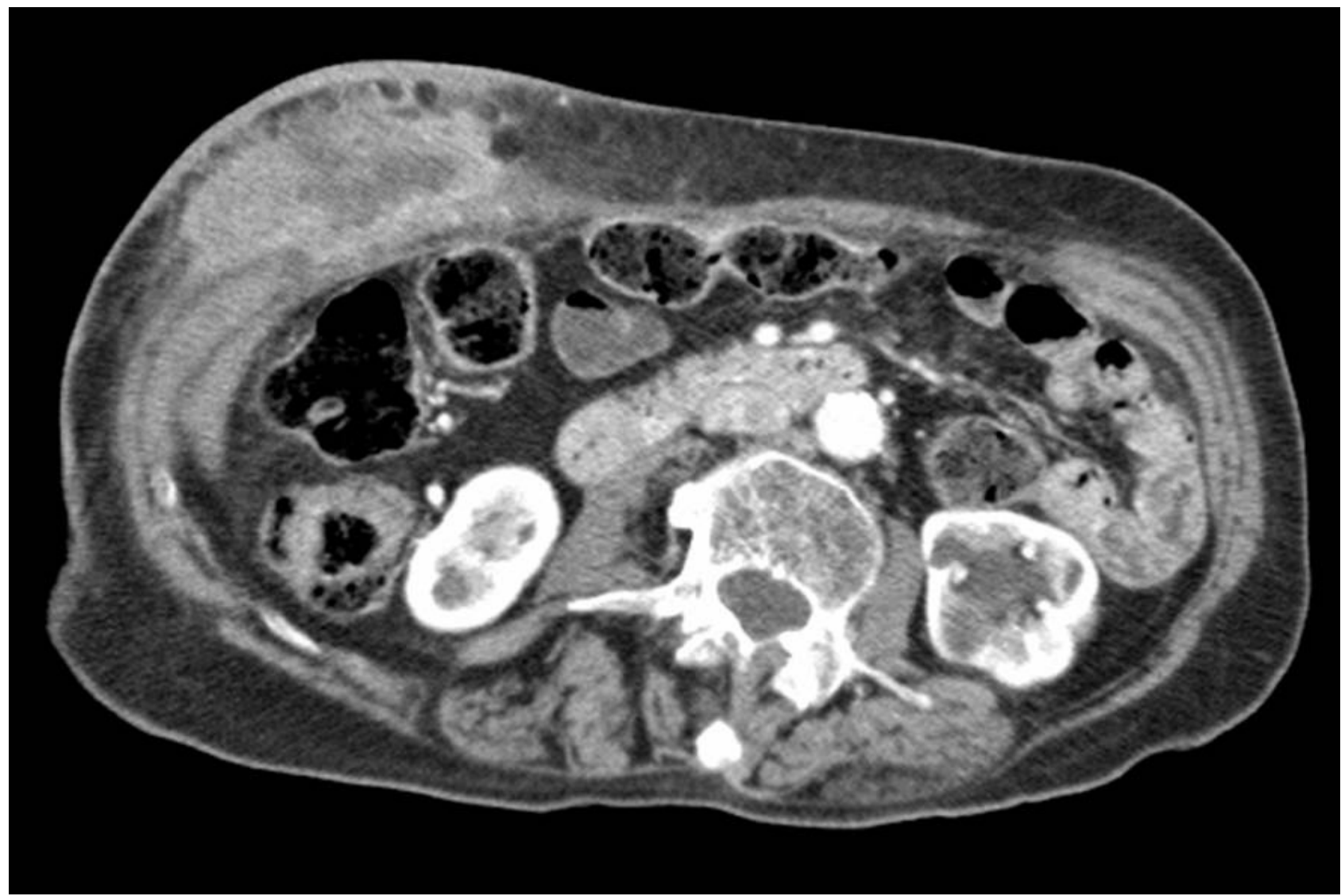

Figure 5 - Transversal enhanced CT image showing right flank subcutaneous irregular collection with significant peripheral fat stranding 
xanthoma cells. In the surgical literature the incidence of xanthogranulomatous cholecystitis is reported to be $0.7 \%$ to $13.2 \%,{ }^{9}$ therefore not being so rare as initially thought. The majority of cases occur in females at the $6^{\text {th }}-7^{\text {th }}$ decade, and it has a high relationship with gallstones (80-90\%). Pathologically it is believed that gallstones obstruct the cystic duct and increase the intraluminal pressure, which in turn leads to mucosal ulceration and rupture of occluded Rokitansky-Aschoff sinuses, with subsequent intramural extravasation of inspissated bile and mucin, attracting histiocytes to phagocytize the insoluble cholesterol. ${ }^{10}$ Clinically it presents with cholecystitis or obstructive jaundice. The principal characteristic is thickening of the gallbladder wall with a tendency to adhere to neighboring organs, even leading to fistula formation, ${ }^{11}$ or as in this case to a subcutaneous collection. The preoperative radiological investigation in our case did not demonstrate findings suggestive of xanthogranulomatous cholecystitis, namely the presence of intramural hypoattenuating nodules occupying $>60 \%$ of the diffusely thickened gallbladder wall with intact mucosal line. ${ }^{12}$ Treatment of xanthogranulomatous cholecystitis involves cholecystectomy because of the need to discard malignant focus within the lesion, since there is

\section{REFERENCES}

1. Flora HS, Bhattacharya S. Spontaneous cholecystocutaneous fistula. HPB. 2001;3:279-80.

2. Henry CL, Ort TG Jr. Spontaneous external biliary fistulas. Surgery. 1949:26:641-6.

3. CruzRJ Jr, Nahas J, de Figueiredo LF. Spontaneous cholecystocutaneous fistula: a rare complication of gallbladder disease. Sao Paulo Med J. 2006;124:234-6.

4. Bennett GL, Balthazar EJ. Ultrasound and CT evaluation of emergent gallbladder pathology. Radiol Clin North Am. 2003;41:1203-16.

5. Rubens DJ. Ultrasound Imaging of the biliary tract. Ultrasound Clin. 2007;2:391-413.

6. Birch BR, Cox SJ. Spontaneous external biliary fistula uncomplicated by gallstones. Postgrad Med J. 1991;67:391-2.

7. Niemeier OW. Acute free perforation of the gall-bladder. Ann Surg. 1934:99:922-4.

8. Nayman J. Empyema necessitatis of the gall-bladder. Med J Aust. an association with gallbladder carcinoma. ${ }^{12}$

The treatment of the complication reported in this case involves the resection of both the communication tract and the gallbladder, ${ }^{13}$ and this can be achieved in a single stage procedure $^{3}$ or in a two-stage procedure, including broadspectrum antibiotics, drainage of the abscess and elective cholecystectomy with excision of the tract, ${ }^{14}$ which was performed. As this condition commonly occurs in elderly and debilitated patients, treatment must be tailored to the patient.

\section{CONCLUSION}

Ultrasonography and computed tomography are the best imaging modalities for diagnosing this complication; furthermore we believe that in unexplained cases of abdominal wall suppuration or cellulitis, these two modalities are complementary and should therefore be performed.

\section{CONFLICTS OF INTEREST}

The authors declare that there are no conflicts of interest.

\section{FUNDING SOURCES}

No subsidies or grants contributed to this work.

1963;1:429-30.

9. Kwon AH, Matsui $\mathrm{Y}$, Uemura Y. Surgical procedures and histopathologic findings for patients with xanthogranulomatous cholecystitis. J Am Coll Surg. 2004;199:204-10.

10. Goodman ZD, Ishak KG. Xanthogranulomatous cholecystitis. Am J Surg Pathol. 1981:5:653-9.

11. Yang $T$, Zhang $B H$, Zhang J, Zhang $Y J$, Jiang $X Q$, Wu MC. Surgical treatment of xanthogranulomatous cholecystitis: experience in 33 cases. Hepatobiliary Pancreat Dis Int. 2007;6:504-8.

12. Jain S, Saluja SS, Sharma AK, Sant H, Mishra PK. Xanthogranulomatous cholecystitis: catching the culprit--clinical and imaging analysis. Dig Surg. 2012;29:187-93.

13. Metsemakers WJ, Quanten I, Vanhoenacker F, Spiessens T. Spontaneous cholecystocutaneous abscess. Jbr-btr. 2010;93:198-200.

14. Sayed L, Sangal S, Finch G. Spontaneous cholecystocutaneous fistula: a rare presentation of gallstones. J Surg Case Rep. 2010;5:5.

Próximo Caso Clínico / Nerxt Case Report:

\title{
Síndrome de Vasoconstrição Cerebral Reversível: uma Causa Importante de Acidentes Vasculares Cerebrais no Puerpério
}

\author{
Reversible Cerebral Vasoconstriction Syndrome: an Important Cause of \\ Stroke in the Puerperium
}




\title{
Subcutaneous Abscess Secondary to Xanthogranulomatous Cholecystitis
}

\author{
Acta Med Port 2014:27:511-514
}

Publicado pela Acta Médica Portuguesa, a Revista Científica da Ordem dos Médicos

Av. Almirante Gago Coutinho, 151

1749-084 Lisboa, Portugal.

Tel: +351218428 215

E-mail: submissao@actamedicaportuguesa.com

www.actamedicaportuguesa.com

ISSN:0870-399X | e-ISSN: 1646-0758

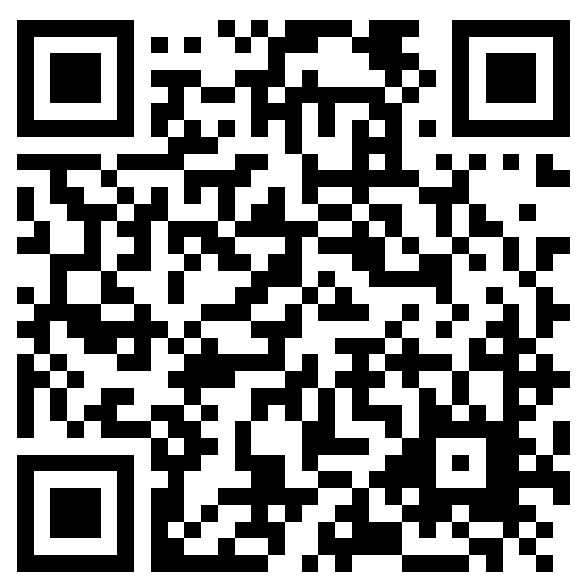

